\title{
IMPORTANCE OF SUGAR BEET IN THE FRAME OF CARBON QUANTIFICATION IN THE CZECH REPUBLIC
}

\author{
KATERINA VRUBLOVA*, JARMILA FILIPPOVOVA \\ Palacky University, Faculty of Science, Dpt. of Development and Environmental Studies, \\ Olomouc, Czech Republic \\ *Corresponding authore-mail: katerina.vrublova@gmail.com
}

Received: $23^{\text {th }}$ October 2018, Accepted: $24^{\text {th }}$ October 2018

\begin{abstract}
Climate change impacts are related to the state and land-use of agriculture landscape. Best agriculture practice principles in climate change conditions should be focused on agriculture management maintaining and enhancing the organic matters stocks in the soils. Biogeochemical carbon cycle has a serious role there. The paper deals with sugar beet dominance among agriculture crop in the frame of carbon quantification in the Czech Republic. Modelling of carbon quantification in arable lands and aboveground biomass of agriculture crop indicate importance of sugar beet, which is a dominant kind of agriculture crop for carbon sequestration in the Czech Republic.
\end{abstract}

Keywords: Agricultural landscape, carbon quantification, climate changes, sugar beet.

The fundamental factors determining the dynamics of carbon stock in the soil organic matter of agricultural soils are the physical and chemical characteristics of soil, vegetation, climate and agro-technology (Marek et al., 2011). The ongoing climate change and associated agricultural drought episodes are very closely related to the state and use of the land (Machar et al., 2012; Machar, 2012). The principles of good (sustainable) agricultural practices under changing climate conditions should, among other things, be geared to agro-technical practices that maintain and increase the proportion of organic matter in soil (Pechanec et al., 2017). Organic matter content of soil is one of the basic indicators of agricultural land quality. The degree of aggregation of soil particles depends on the proportion of organic matter in soil, and the stability of soil aggregates is increasing with increasing amounts of organic carbonaceous substances, which positively affects soil water supplies, soil resistance to water and wind erosion, and availability of the main nutrients for plants (Šarapatka et al., 2008).

Quantification of carbon stock in soil in a larger geographic region is subject to some degree of uncertainty as with any other environmental database on the landscape (Pechanec et al., 2015). However, for the so-called emission inventory of the green sector (agriculture and forestry) in the Czech Republic (Penman et al., 2003), the summary data on carbon stock in agricultural and forest soils is necessary (Machar et al., 2017). In this paper, we briefly present some results from the model nationwide quantification of carbon stock (Šefrna \& Janderková, 2007) and we draw attention to the extraordinary importance of sugar beet within agricultural crops grown in the Czech Republic in this context. The model 
quantification of the soil carbon stock (Qi) in tonnes per hectare in the agricultural land of the Czech Republic is based on the calculation of Qi = CiDiEi (1-Gi) where the carbon stock content $\mathrm{Ci}(\%)$, density Di $(\mathrm{g} / \mathrm{cm} 3)$ and volume of fraction of coarse particles Gi (Batjes, 1996; Schwartz \& Namri, 2002). The arable land in beet production areas in the Czech Republic occupies a total area of $4788 \mathrm{~km}^{2}$. The calculation of the carbon stock of this arable land has shown a total value of 38529979 tonnes of carbon. Compared to the most productive ecosystems in the lowland regions of the Czech Republic, which are floodplain forests (Machar, 2009), this value is relatively low because agricultural crops do not enrich the upper soil horizons with carbon in the form of leaf fall like deciduous forests do.

However, if we consider only agricultural soils and take into account the carbon stock bound in vegetation of agricultural crops, sugar beet areas significantly dominate the quantified carbon stock in the Czech Republic. For the calculation of biomass and crop production on arable land, data on cropland and average yields from the Czech Statistical Office were used. Values were recalculated to $100 \%$ dry matter and subsequently to pure carbon. This made it possible to calculate the amount of carbon in the average annual biomass on arable land interpolated to individual districts of the Czech Republic. The lowest carbon stock in arable crops ( $3 \mathrm{t} / \mathrm{ha}$ ) was calculated for the districts of Děčín, Ústí nad Labem and Jablonec nad Nisou, the highest values (over 5 t/ha) were for Olomouc, Jičín, Prostějov and Hradec Králové districts. These districts are characterized by a higher proportion of beet production, which has the highest biomass per hectare of arable land of all agricultural crops.

According to the bio-geographic prediction climate model (Machar et al., 2017), the growing conditions for sugar beet will be subject to significant changes in the Czech Republic in the future, with the climatically favourable area for growing sugar beet extending considerably (Kopecka et al., 2013).

If soil carbon was considered to be a form of "national natural wealth" as indicated by the study (Kilianova et al., 2012), then the model of quantification of soil carbon stock could be a major argumentation tool for promoting the application of Good Agricultural Practice within European agricultural subsidy policy.

\section{REFERENCES}

Batjes, N.H. (1996). Total carbon and nitrogen in the soils of the world. European Journal of Soil Science, 47, 1996, s. 151-163.

Kilianova, H. et al. (2012). Analysis of the Evolution of the Floodplain Forests in the Aluvium of the Morava River. In 12th International Multidisciplinary Scientific Geoconference, SGEM 2012, Vol. IV, Albena, Bulgaria, 2012, s. 1-8.

Kopecka, V. et al. (2013). The Impact of Climate Changes on Sugar Beet Growing Conditions in the Czech Republic. Listy cukrov. řepař., 129, 2013 (11), s. 326-329.

Machar, I. et al. (2017). Biogeographic model of climate conditions for vegetation zones in Czechia. Geografie, 122, 2017 (1), s. 64-82.

Machar, I. et al. (2017). Modelling of Climate Conditions in Forest Vegetation Zones as a Support Tool for Forest Management Strategy in European Beech Dominated Forests. Forests, 8, 2017 (3), article number 82. DOI: 10.3390/f8030082.

Machar, I. et al. (2012). Protection of nature and landscapes in the Czech Republic Selected current issues and possibilities of their solution. Olomouc: Palacky University, 2012, s. 9-853. ISBN 978-80-244-3041-6.

Machar, I. (2009). Conservation and Management of Floodplain Forests in the Protected 
Vrublova K., Filippovova J.: Importance of sugar beet in the frame of carbon quantification in the Czech $\underline{\text { Republic }}$

Landscape Area Litovelske Pomoravi (Czech Republic) Introduction. Olomouc: Palacky University, 2009, s. 7-108. ISBN 978-80-244-2355-5.

Machar, I. (2012). Changes in Ecological Stability and Biodiversity of a Floodplain Landscape. Olomouc: Palacky University, 2012, s. 73-87. ISBN 978-80-244-2997-7.

Marek, M.V. et al. (2011). Carbon in ecosystems of the Czech Republic under climate changes. Praha: Academia, 2011, 253 s. ISBN 978-80-200-1876-2.

Pechanec, V. et al. (2015). Decision support tool for the evaluation of landscapes. Ecological Informatics, 30, 2015, s. 305-308. DOI: 10.1016/j.ecoinf.2015.06.006.

Pechanec, V. et al. (2017). Prediction of Climate Change Impacts on Sustainbale Agricultural Management in the Czech Republic. Fresenius Environmental Bulletin, 26, 2017 (12), s. 7580-7586.

Penman, J. et al. (2003). Good Practice Guidance for Land Use Change. Hayama (Japan): IPPC/OECD/IEA/IGES, 2003, $121 \mathrm{~s}$.

Schwartz, D.; Namri, M. (2002). Mapping the total organic carbon in the soils of the Congo. Global and Planetary Change, 33, 2002, s. 77-93.

Šarapatka, B. et al. (2008). Agricultural and Landscape: Joining to each other. Olomouc: Palacky University, 2008, 271 s., ISBN 978-80-244-1885-8.

Šefrna, L., Janderková, J. (2007). Oxidizable carbon content in soil units of the map 1:500 000; Agricultural soils. Reports of grant Vav 640/18/03 Czech Carbo - Research on carbon in terrestrial ecosystems of the Czech Republic. $7 \mathrm{~s}$. 